Jurnal Biologi dan Pembelajarannya, Vol 7 No 2, Oktober 2020. Pp: 23-27

e-ISSN: $2406-8659$

\title{
PENGARUH MODEL DISCOVERY LEARNING MENGGUNAKAN KAMUS BERGAMBAR SISTEM REPRODUKSI MANUSIA TERHADAP HASIL BELAJAR KOGNITIF PESERTA DIDIK
}

\author{
Fatikhatun Nikmatus Sholihah'1 ${ }^{1}$, Ospa Pea Yuanita Meishanti' ${ }^{2}$, Asmi 'Aqidatul 'Izzah ${ }^{3}$ \\ ${ }^{1,2}$ Prodi pendidikan Biologi,Universitas K.H A. Wahab Hasbullah,Jl Garuda no 9 Tambakrejo Jombang \\ ${ }^{3}$ Mahasiswa Pendidikan Biologi, FIP, Universitas KH.A Wahab Hasbullah \\ e-mail: ${ }^{1}$ fatiha.achmad@unwaha.ac.id
}

\begin{abstract}
Abstrak
Penggunaan model dan media pembelajaran yang tepat merupakan upaya untuk mencapai tujuan pembelajar an. Pada materi sistem reproduksi banyak peserta didik merasa kesulitan memahami materi sehingga hasil bel ajar kognitif peserta didik belum maksimal. Banyaknya istilah-istilah latin yang sulit untuk diingat dan banyakn ya organ -organ penyusun sistem reproduksi menjadi faktor peserta didik sulit memahami materi sistem reprod uksi. Tujuan penelitian untuk mengetahui pengaruh model discovery learning menggunakan kamus bergambar sistem reproduksi manusia terhadap hasil belajar kognitif peserta didik. Jenis penelitian ini adalah Pra eksperim ent dengan metode one group pretest-posttest design. Teknik pengumpulan data berupa tes (pretes dan postes ). Instrument yang digunakan berupa soal (pretest dan postes). Analisis data yang digunakan yaitu hasil belajar kognitif peserta didik serta uji t berpasangan (paired sample t test) dengan bantuan program SPSS 16 . Hipotesis yang digunakan yaitu $\mathrm{H}_{0}$ tidak ada pengaruh dan $\mathrm{H}_{1}$ terdapat pengaruh model pembelajaran terhadap hasil bel ajar. Hasil penelitian menunjukkan bahwa hasil belajar kognitif peserta didik meningkat dengan rata-rata prete st 64,72 menjadi 79,3 untuk postest. Hasil uji t menunjukkan bahwa Sign $\leq 0,05$ yaitu 0,00. Hal ini menunjukkan bahwa $\mathrm{H}_{0}$ ditolak dan $\mathrm{H}_{1}$ diterima yang artimya ada pengaruh model pembelajaran discovery learning dengan $h$ asil belajar peserta didik.
\end{abstract}

Kata kunci-Guided Discovery Learning, Hasil Belajar Kognitif, Kamus Bergambar,

\section{PENDAHULUAN}

Penggunaan model dan media pembelajaran yang tepat merupakan upaya untuk mencapai tujuan pe mbelajaran serta memperoleh hasil belajar yang maksimal. Pada materi sistem reproduksi banyak peserta didik merasa kesulitan memahami materi sehingga hasil belajar kognitif peserta didik belum maksimal. Banyaknya is tilah-istilah latin yang sulit untuk diingat serta banyaknya organ-organ penyusun sistem reproduksi menjadi fak tor peserta didik sulit memahami materi sistem reproduksi. Salah satu model pembelajaran yang dapat digunak an untuk menyampaikan materi sistem reproduksi yaitu model discovery learning.

Model discovery learning merupakan pembelajaran berdasarkan penemuan dan bersifat konstruktivis. Widyastuti (2015) menjelaskan bahwa model pembelajaran ini memiliki skenario pembelajaran untuk memeca hkan masalah mereka sendiri [1]. Takdir (2012) juga menambahkan bahwa model discovery learning dapat me mberikan banyak kesempatan kepada peserta didik untuk terlibat langsung dalam kegiatan pembelajaran [2].B erdasarkan kedua pendapat tersebut, diharapkan peserta didik dapat menemukan konsep atau istilah sistem re produksi dengan mudah. Senada dengan Arsyad (2017) bahwa materi yang disampaikan dengan menggunakan model discovery learning akan lebih mudah diterima dan dipahami [3].

Model discovery learning dapat melatih mahasiswa memecahkan suatu masalah. Masalah yang diama ti dalam pembelajaran ini adalah pemahaman konsep tentang materi sistem reproduksi. Hal ini didukung ol eh Windasari dan Hasanudin (2016) bahwa model discovery learning dapat dipilih karena mo del ini telah terbukti dapat membantu peserta didik dalam memahami materi [4]. Yuliana (201 9) dalam penelitiannya menyebutkan tentang kelebihan pada model discovery learning sebagai berikut: a) Me mbantu siswa untuk memperbaiki dan meningkatkan keterampilan-keterampilan dan proses-proses kognitif, b) Model ini memungkinkan siswa berkembang dengan cepat dan sesuai dengan kecepatannya sendiri, c) Mening katkan tingkat penghargaan pada siswa, karena unsur berdiskusi, d) Mampu menimbulkan perasaan senang da $\mathrm{n}$ bahagia karena siswa berhasil melakukan penelitian, dan e) Membantu siswa menghilangkan skeptisme (kera gu-raguan) karena mengarah pada kebenaran yang final dan tertentu atau pasti [5]. Tahapan-tahapan model $p$ embelajaran penemuan ini dimulai dari stimulation (stimulasi/pemberian rangsangan), problemstatement (per yataan/identifikasi masalah), data collection (pengumpulan data), data processing (pengolahan data), verificati on (pembuktian), generalization (generalisasi/menarik kesimpulan) (Seda et al., 2019)[6]. 
Jurnal Biologi dan Pembelajarannya, Vol 7 No 2, Oktober 2020. Pp: 23-27

e-ISSN: $2406-8659$

Penerapan model discovery learning tidak lepas dari media pembelajaran. Pentingny a media pembelajaran dijelaskan oleh Mustiqon (2012) bahwa pemilihan media belajar dapa t meningkatkan hasil belajar peserta didik salah satunya hasil belajar kognitif [7]. Hasil belaja $r$ kognitif merupakan perubahan perilaku yang terjadidalam kawasan kognisi yaitu kemampu an tunggal dalam domain kognitif yang meliputi beberapa jenjang atau tingkat (Purwanto, 20 10) [8]. Salah satu media yang dapat digunakan yaitu media kamus bergambar. Media kamus bergambar merupakan salah satu alat bantu alternatif untuk membantu peserta didik mema hami materi yang membutuhkam penguasaan kosakata dan istilah-istilah yang sulit dipaham i. Ismawarti (2014) menjelaskan bahwa kamus bergambar merupakan buku yang memuat ka ta dilengkapi istilah dengan penjelasan dan gambar serta mengutamakan kejelasan gambar $\mathrm{s}$ ehingga peserta didik dapat memahami penjelasan materi dengan mudah [9]. Senada denga n Putri dan Shodiq (2018) bahwa media pembelajaran kamus bergambar dipilih karena medi a kamus bergambar dapat meningkatkan pemahaman kosakata [10].

Berdasarkan permasalahan diatas, maka penelitian ini bertujuan untuk mengetahui pengaruh model discovery learning dengan menggunakan media kamus bergambar sistem reproduksi manusia terhadap hasil belajar kognitif peserta didik. Manfaat dari penelitian ini diharapkan dapat dapat menambah motivasi peserta didik dan memudahkan dalam memahami materi sistem reproduksi manusia. Selain itu, dapat menambah variasi model dan media pembelajaran yang digunakan dalam kegiatan belajar mengajar sehingga dapat meningkatkan pemahaman peserta didik.

\section{METODE PENELITIAN}

Jenis penelitian yang digunakan yaitu pra eksperimen dengan metode one group pret est posttest design. Pada desain ini terdapat test sebelum perlakuan (pretes) dan tes setelah perlakuan (postes). Hal ini bertujuan untuk mengetahui hasil belajar kognitif sebelum dan se sudah perlakuan (Sugiyono, 2018) [11]. Metode ini dapat dilihat pada Gambar 1.

\section{$\mathrm{O} 1 \times 02$}

\section{Gambar 1. Desain One group pretest posttest}

Keterangan:

O1: hasil belajar kognitif peserta didik sebelum perlakuan (model discovery learning menggunakan media kamu $s$ bergambar sistem reproduksi manusia).

O2: hasil belajar koginit peserta didik setelah perlakuan (model discovery learning menggunakan media kamus bergambar sistem reproduksi manusia

Penelitian ini dilakukan pada tanggal 1-14 Mei 2020 secara daring. Hal ini dikarenakan adanya musibah pandemi covid19. Subyek penelitian ini adalah kelas XI MIPA 2 yang berjumlah 36 peserta didik. Lokasi penelitian di MA unggulan KH. Ab Wahab Hasbulloh Jombang. Penelitian ini dilakukan dalam dua kali pertemuan menggunakan whatsapp application. Pertemuan pertama peserta didik diberikan soal pretes untuk mengetahui hasil belajar kognitif sebelum perlakuan. Media kamus bergambar yang digunakan menggunakan format pdf. Pertemuan pertama mengidentifikasi gambar buta organ reproduksi manusia yang tersedia pada LKS Organ Reproduksi Manusia menggunakan media kamus bergambar sistem reproduksi manusia. Peserta didik mengidentifikasi, verifikasi, serta menyimpulkan hasil identifikasi dengan cara mencocokkan hasil pengamatannya dengan organ reproduksi yang ada dalam kamus bergambar. Pertemuan kedua peserta didik diberikan kesempatan untuk merumuskan masalah (membuat pertanyaan) pada LKS Fungsi Organ Reproduksi Manusia. Peserta didik menalar jawaban sementara dari rumusan masalah tersebut kemudian dipersilahkan untuk memulai mengidentifikasi menggunakan media kamus bergambar sistem reproduksi manusia. Setelah melakukan kegiatan sampai tahap generalisasi, peserta didik diberikan soal posttest untuk mengetahui hasil belajar kognitif setelah perlakuan.

Teknik pengumpulan data berupa tes (pretes dan postes). Tes merupakan teknik pengump ulan data yang bersifat mengukur. Tes pada penelitian ini berupa soal prestest dan posttest yang digunakan unt 
Jurnal Biologi dan Pembelajarannya, Vol 7 No 2, Oktober 2020. Pp: 23-27

e-ISSN: $2406-8659$

uk mengukur hasil belajar kognitif peserta didik sebelum dan sesudah perlakuan. Instrumen penelitian yan g digunakan adalah perangkat pembelajaran dan soal pretes dan postes. Perangkat pembelajaran merupak an perangkat yang digunakan untuk mengajar yang terdiri dari silabus dan rencana pelaksanaan pembelajaran ( RPP), dan lembar kerja siswa (LKS) dengan menggunakan fase discovey learning. Selain itu, instrumen yan g digunakan untuk mengukur hasil kognitif peserta didik yaitu soal (pretest dan postes). Soal ini terdiri dari soal pilihan ganda yang berjumlah 20. Analisis tes hasil belajar peserta didik dianalisis untuk me ngetahui hasil pretes dan postes. Perhitungan tersebut yang digunakan dapat dilihat pada rumus dibawah ini.

$$
\text { Nilai }=\frac{\text { jumlah skor peserta didik }}{\text { jumlah skor maksimum }} \times 100
$$

Setelah mendapat nilai pretes dan postes, dilanjutkan menggunakan uji t berpasanga $\mathrm{n}$ (paired sample $t$ test) dengan bantuan program SPSS 16. Uji t yang digunakan adalah Paire $d$-Sample $t$ test (uji t berpasangan karena melibatkan dua pengukuran pada subyek yang sam a terhadap suatu pelakuan tertentu. Kriteria pengujian berdasarkan signifikan (Sig) adalah Jik a $\mathrm{Sig}<0,05$, maka $\mathrm{H}_{0}$ ditolak dan $\mathrm{H}_{1}$ diterima, begitu juga sebaliknya. $\mathrm{H}_{0}$ artinya tidak ada pe ngaruh model pembelajaran menggunakan media kamus bergambar terhadap hasil belajar $\mathrm{d}$ an $\mathrm{H}_{1}$ artinya ada pengaruh model pembelajaran menggunakan media kamus bergambar ter hadap hasil belajar.

\section{HASIL DAN PEMBAHASAN}

Analisis tes hasil belajar yaitu menganalisis data hasil belajar kognitif 36 siswa pada pretest dan postes t. Hasil nalisis tes hasil belajar dapat dilihat pada Gambar 2.

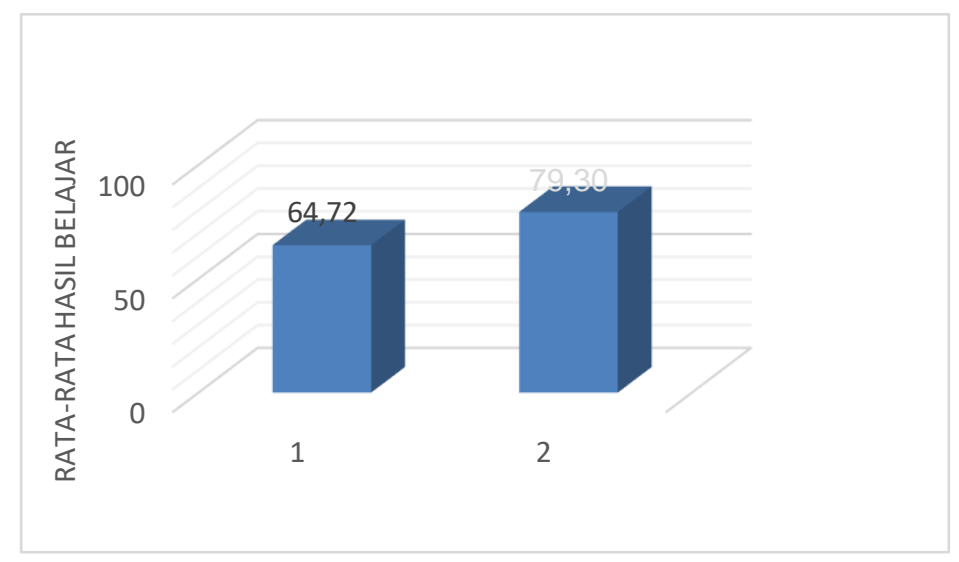

Gambar 2. Rata-rata Hasil Belajar Kognitif Peserta Didik

Berdasarkan Gambar 2 dapat diketahui bahwa nilai hasil belajar kognitif postes naik jika dibandingkan dengan nilai hasil belajar pretes. Perolehan nilai didapat dari skor yang diperoleh peserta didik dibagi skor maks imal. Nilai hasil belajar terendah pada pretes 30 dan nilai tertinggi 100, sedangkan pada postes nilai terendah 5 0 dan nilai tertinggi 100 . Nilai yang diperoleh tidak lepas dari sebab dan faktor yang mempengaruhi yaitu soal y ang dianggap sulit oleh peserta didik yaitu mencari pasangan organ reproduksi dengan fungsinya. Hal ini memb uat peserta didik terkecoh sehingga banyak yang menjawab salah. Selain itu, pemberian soal menggunakan go ogle form membatasi peserta didik untuk mengoreksi lagi apa yang sudah dijawabnya. Meskipun menggunakan google form, instrumen tersebut tidak membuat hasil belajar menurun. Peranan instrumen sangat penting kare na instrumen berfungsi mengungkapkan fakta menjadi suatu data. Seperti yang diungkapkan oleh Anitah (2010 ) bahwa instrumen yang memiliki kriteria yang baik maka mutu penelitiannya juga baik, begitu juga sebaliknya [ 12]. Hal ini dibuktikan dengan hasil belajar kognitif peserta didik mendapat nilai maksimal meskipun instrumen yang digunakan dalam bentuk daring.

Nilai rata-rata hail belajar kognitif peserta didik pada pretest 64,72 sedangkan pada posttest 79,3 . Has il pretes dan posttes menunjukkan bahwa dengan menggunakan model discovery learning menggunakan kamu $\mathrm{s}$ bergambar sistem reproduksi manusia dapat memudahkan peserta didik dalam memahami materi dan kosak 
Jurnal Biologi dan Pembelajarannya, Vol 7 No 2, Oktober 2020. Pp: 23-27

e-ISSN: $2406-8659$

ata yang belum dipahami. Hal ini sesuai dengan penelitian Salmi (2019) bahwa model discovery learning dapat meningkatkan hasil belajar peserta didik [13]. Hasil belajar kognitif peserta didik menggunakan tes diperkuat $d$ engan hasil uji-t berpasangan. Hal ini dapat dilihat pada tabel dibawah ini.

Tabel 1. Hasil uji t Berpasangan (paired sample t-test)

\begin{tabular}{|c|c|c|c|c|c|c|c|c|}
\hline & \multicolumn{8}{|c|}{ Derajat kepercayaan 95\% } \\
\hline & $\begin{array}{l}\text { Rata-rat } \\
\text { a }\end{array}$ & $\begin{array}{l}\text { Standart } \\
\text { deviasi }\end{array}$ & $\begin{array}{l}\text { Standart k } \\
\text { esalahan }\end{array}$ & $\begin{array}{l}\text { Batas ba } \\
\text { wah }\end{array}$ & $\begin{array}{l}\text { Batas at } \\
\text { as }\end{array}$ & 1 & Df & signifikansi \\
\hline $\begin{array}{l}\text { Pretest } \\
- \\
\text { postes }\end{array}$ & -14.548 & 11.854 & 1.97580 & -18.59 & -10.572 & -738 & 35 & 0.000 \\
\hline
\end{tabular}

Berdasarkan Tabel 1 didapat bahwa Sign< 0,05 yaitu 0,000. Maka dapat dinyatakan bahwa terdapat pe rbedaan yang signifikan antara nilai pretes dan postes. Perbedaan ini dapat juga diartikan bahwa hasil belajar $\mathrm{k}$ ognitif mahasiswa meningkat. Hasil belajar kognitif yang meningkat menunjukkan bahwa pemahaman konsep $t$ entang sistem reproduksi juga meningkat. Pemahaman konsep ini juga membuktikan bahwa model discovery $I$ earning menggunakan kamus bergambar berpengaruh terhadap hasil belajar kognitif peserta didik. Pengaruh $\mathrm{i}$ ni berdampak juga pada keaktifan peserta didik dalam pembelajaran serta lebih mandiri dalam mencari inform asi sendiri melalui kamus bergambar. Hal ini sesuai dengan penelitian Fitriyani, Rahmi, dan Didi (2017) yaitu ter dapat pengaruh penerapan model pembelajaran discovery learning terhadap hasil belajar peserta didik[14].

Hasil belajar kognitif yang meningkat tidak lepas dari media kamus bergambar sistem reproduksi man usia. Kamus ini merupakan media yang memudahkan peserta didik mengingat istilah latin. Kamus bergambar si stem reproduksi manusia dilengkapi dengan nama, keterangan dan gambar organ yang disusun berdasarkan ab jad A-Z sehingga peserta didik mudah menggunakannya. Selain itu, kelebihan media pembelajaran ka mus bergambar adalah dapat meningkatkan pemahaman istilah yang dianggap sulit (Putri da n Shodiq ,2018) [10]. Peserta didik yang paham akan istilah pada materi sistem reproduksi, maka pemaham an konsep peserta didik akan meningkat sehingga dapat berpengaruh terhadap hasil belajar kognitif peserta di dik. Hal ini sesuai dengan penelitian sebelumnya yang dilakukan oleh Linalutfa (2019) bahwa hasil angket respo n peserta didik menunjukkan bahwa peserta didik lebih mudah memahami kata ilmiah pada materi reproduksi dan gambar yang disajikan dengan jelas disertai gambar[15]. Hasil tersebut senada dengan penelitian Ismawart i (2014) bahwa terdapat peningkatan hasil belajar peserta didik setelah menggunakan kamus bergambar[8].

\section{SIMPULAN}

Hasil penelitian menunjukkan bahwa hasil belajar kognitif peserta didik meningkat dari 64,72 menjadi 79,30. Berdasarkan hasul uji t dengan bantuan SPSS, didapat Sign< 0,05 yaitu 0,000. Maka dapat disimpulkan $b$ ahwa model discovery learning menggunakan kamus bergambar sistem reproduksi manusia berpengaruh terha dap hasil belajar kognitif peserta didik Madrasah Aliyah Unggulan KH.Abd Wahab Hasbulloh.

\section{SARAN}

Model discovery learning lebih baik lagi jika menggunakan media kamus bergambar dengan kegiatan $p$ embelajaran berbasis teknologi. Mengingat masa pademi, media berupa buku tidak mudah dilakukan ketika pe mbelajaran daring.

\section{UCAPAN TERIMA KASIH}

Terima kasih kepada guru biologi dan peserta didik Madrasah Aliyah Unggulan KH.Abd Wahab Hasbull oh yang telah berpartisipasi terhadap penelitian ini. Terima kasih juga kepada pihak yang berpastisipasi secara I angsung maupun tidak langsung sehingga artikel ini dapat dipublikasikan.

\section{DAFTAR PUSTAKA}

[1] Widyastuti, E. 2015. Penerapan Model Discovery Learnig pada Materi Konsep Ilmu Ekonomi. Prosiding seminar nasional. eprints.uny.ac.id. Diakses 20 Januari 2020. 
Jurnal Biologi dan Pembelajarannya, Vol 7 No 2, Oktober 2020. Pp: 23-27

e-ISSN: $2406-8659$

[2] Takdir, M. 2012. Pembelajaran Discovery Learning dan Mental Vacation Skill. Jogjakarta. DIVA Press.

[3] Arsyad,A. 2017. Media pembelajaran. Jakarta. Rajagrafindo Persada.

[4] Yuliana, N. (2019). Penggunaan Model Pembelajaran Discovery Learning Dalam Peningkatan Hasil Belajaran Siswa Di Sekolah Dasar. Pedagogi: Jurnal IImu Pendidikan, 18(2), 56. https://doi.org/10.24036/fip.100.v18i2.318.000-000.

[5] Seda, E., Ain, N., \& Sundaygara, C. (2019). Pengaruh Model Pembelajaran Discovery Learning dengan Menggunakan Media Video Terhadap Hasil Belajar Siswa. Jurnal Pendidikan (Teori dan Praktik), 4(1), 59. https://doi.org/10.26740/jp.v4n1.p59-62.

[6] Ismawarti, D. 2014. Pengembangan kamus bergambar peralatan membuat dan menyajikan minuman non alkohol dan beralkohol untuk siswa jasa boga kelas XI SMKN 4 Yogyakarta. Skripsi tidak diterbitkan. Yogyakarta. UNY.

[7] Mustiqon. 2012. Pengembangan Media dan Sumber Pembelajaran. Jakarta. PT Prestasi Pustakarya

[8] Purwanto. 2010. Evaluasi Hasil Belajar. Yogyakarta. Pustaka Pelajar.

[9] Windasari dan Hasanudin. 2016. Pengaruh Model Guided Discovery Terhadap Kesadaran Metakognitif dan Hasil Belajar Kognitif Peserta Didik Pada Materi Sistem Reproduksi Manusia di MAS Babun Najah Banda Aceh. Banda Aceh. Universitas Syiah Kuala. Jurnal Biotik. 4(1): 66-67.

[10]Putri, B dan Shodiq, M. 2018. Media Kamus Bergambar Bahasa Indonesia Untuk Meningkatkan Pemahaman Kosakota Siswa Tunarungu. Universitas Negeri Malang. Jurnal Ortopedagogia. 4(2): 109-114.

[11]Sugiyono. 2018. Metodologi Penelitian Kuantitatif, Kualitatif, dan R\&D. Bandung. Alfabeta.

[12]Salmi. 2019. Penerapan Model Discovery Learning Dalam Meningkatkan Hasil Belajar Ekonomi Peserta Didik Kelas XII IPS 2 SMA 13 PALEMBANG. Jurnal Profit. 6(1): 1-16.

[13]Fitriyani, Rahmi, S., dan Didi, J, S. 2017. Pengaruh Penerapan Model Pembelajaran Discovery Learning Terhadap Hasil Belajar Siswa Kelas X IPA SMA Negeri 13 Palembang Pada Materi Dunia Tumbuhan. Prosising Seminar Nasional Pendidikan IPA. conference.unsri.ac.id. Diakses tanggal 8 Juni 2020.

[14]Linaluthfa, T. 2019. Pengembangan Media Pembelajarn Kamus Bergambar Pada Materi Sistem Reproduksi Manusia Untuk Peserta Takroruddurus di Pondok Pesantren Al-Fathimiyyah. Jombang. UNWAHA. 